\title{
LIG4 syndrome
}

INSERM

\section{Source}

INSERM. (1999). Orphanet: an online rare disease and orphan drug data base. LIG4 syndrome. ORPHA:99812

LIG4 syndrome is a hereditary disorder associated with impaired DNA double-strand break repair mechanisms and characterized by microcephaly, unusual facial features, growth and developmental delay, skin anomalies, and pancytopenia, which is associated with combined immunodeficiency (CID). 